\title{
Are only floods with large discharges threatening? Flood characteristics evolution in the Yangtze River Basin
}

\author{
Suning Liu ${ }^{1,2}$, Yi Zheng ${ }^{1,2}$, Lian Feng ${ }^{1,2}$, Ji Chen ${ }^{3}$, Venkataraman Lakshmi ${ }^{4}$ and Haiyun Shi ${ }^{1,2^{*}}$ (i)
}

\begin{abstract}
This study focuses on the evolution of flood risk in the Yangtze River Basin under climate change, which is a critical issue for socioeconomic development in future. In this study, we (1) compared the 1998 and 2020 floods and found that the destructiveness of a given discharge is now greater than before; (2) revealed three issues related to the above finding; and (3) prospected the future development of up-to-date technologies to better address the issue that floods with high water levels will frequently threaten us. The outcomes of this study would be of great significance to future flood control operation of large river basins.
\end{abstract}

Keywords: Floods, Yangtze River Basin, Backwater effect, Pump drainage measures, Buffering effects of lakes

In recent years, there has been frequent occurrence of extreme weather due to global climate change (Liu et al. 2020; Shi et al. 2020). Watersheds have been heavily modified by engineering measures (reservoir operation, pumping, diversions) as a result of rapid urbanization, hydropower production and irrigation for agricultural uses. The evolution of flood risk under climate change is a critical issue for sustainable development (Reynard et al. 2017). The flood that occurred in July/August 2020 in China's Yangtze River Basin (YRB) provides insights into this issue.

After the 1998 historic flood in the YRB that caused enormous casualties and property losses (Zong and Chen 2000), China greatly improved its engineering capacity to reduce peak discharges in the main stream of the Yangtze River (YR), especially after the Three Gorges Reservoir (TGR) was completed in 2009. In general, a smaller discharge should correspond to a lower water level at a

\footnotetext{
*Correspondence: shihy@sustech.edu.cn

1 State Environmental Protection Key Laboratory of Integrated Surface Water-Groundwater Pollution Control, School of Environmental Science and Engineering, Southern University of Science and Technology,

Shenzhen, Guangdong, China

Full list of author information is available at the end of the article
}

given station if there is little or no change in the cross section. Nevertheless, it is interesting that during the first flood in 2020, the high water level at Hankou station ( $28.77 \mathrm{~m}$, July 12 th 2020 ) was the same as that in 1998 , even though the observed discharge $\left(56,000 \mathrm{~m}^{3} / \mathrm{s}\right)$ was much smaller than that in $1998\left(70,700 \mathrm{~m}^{3} / \mathrm{s}\right)$ (HBMWR and HBYRWRC 2002). It should be noted that the TGR reduced the discharge by $12,800 \mathrm{~m}^{3} / \mathrm{s}(\sim 40 \%$, Fig. 1$)$. Without the TGR, the discharge at Hankou station would have reached $68,800 \mathrm{~m}^{3} / \mathrm{s}\left(=56,000+12,800 \mathrm{~m}^{3} / \mathrm{s}\right.$, close to that in 1998), with a water level much higher than $28.77 \mathrm{~m}$, posing an unprecedented risk of overtopping and levee failure. An important implication is that the destructiveness of a given discharge is now greater than before. There are multiple reasons for this.

First, the backwater effect from downstream cannot be ignored. In early July 2020, the middle and lower reaches of the YR experienced heavy rainfall with a total of about $505 \mathrm{~mm}$ (1.6 times than the historic average), causing the elevated water level to expand from downstream to upstream simultaneously with the movement of the rain band. In addition, the backwater effect of the astronomic tides in early July might be another vital factor. Consequently, the highest water levels occurred earlier at the 


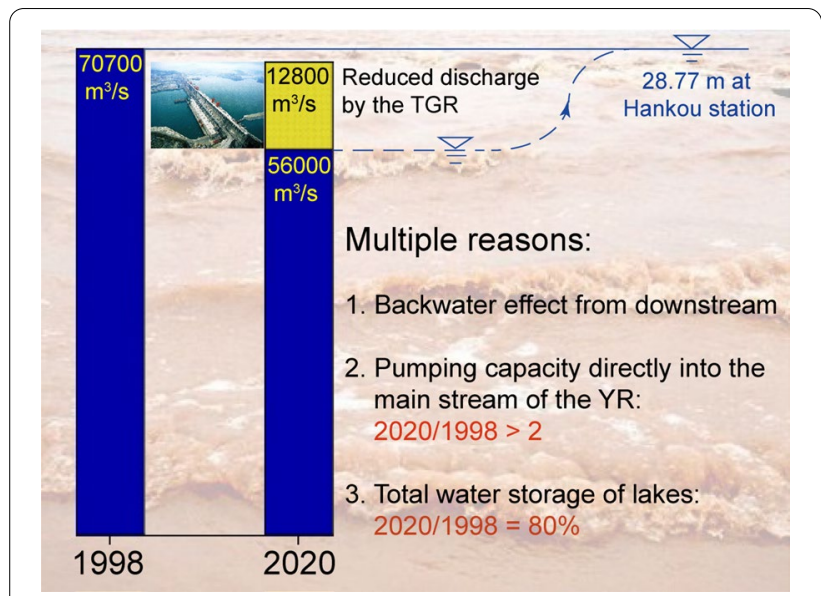

Fig. 1 Comparison of 1998 and 2020 floods in the YRB

downstream stations and later at the upstream stations on 12th July.

Second, pump drainage measures can suddenly raise the water level in the main stream of the YR. Electric pumping can be employed to drain water in urban areas to mitigate waterlogging during heavy rains. The total pumping capacity within the basin has increased greatly in the past two decades, and the proportion of pumping capacity draining stormwater directly into the main stream of the YR almost doubled from 1998 to 2016 (HBMWR and HBYRWRC 2002; ICMWR and HBYRWRC 2019). Therefore, in extreme events, the volume of stormwater pumped into the main stream in 2020 is likely twice as large as that in 1998 (Fig. 1). Such additional water could cause an increase in the water level. Moreover, pump drainage measures may speed-up the flow of water from urban areas to the main stream (from several days to only several hours), which is an important reason why the highest water levels of different stations along the YR all occurred on the same day.

Third, the buffering effects of lakes on flood detention have been weakened due to human activities in recent decades. The total water storage of all the lakes within the YRB declined by approximately 20\% (Fig. 1) from 1998 $\left(37.2 \mathrm{~km}^{3}\right)$ to $2018\left(29.8 \mathrm{~km}^{3}\right)$, mainly due to lake reclamation (involving the conversion of water bodies to agricultural/built-up lands) (Hou et al. 2020). Without the regulation of lakes during flood periods, greater volume of water flows into the main stream of the YR in a relatively shorter time, inducing a rapid rise in water level.

In summary, in the YRB, reservoir operation can lower flood risk by reducing river discharge, while pump drainage measures and lake reclamation increase flood risk during heavy rainfall. This may provide a reference for other river basins facing the similar problems to the YRB (e.g., backwater effects, pump drainage measures, and buffering effects) (van Noordwijk et al. 2017; Stevaux et al. 2020). Future extreme rainfall events will prove costly to life and property. Therefore, up-to-date technologies should be developed and utilized to better address this issue. For instance, the ongoing sponge city development in the urban areas along the main stream should put more effort into enhancing infiltration capacity in urban areas, such that waterlogging and fast flow towards the main stream can be mitigated simultaneously (Nguyen et al. 2019). Additionally, accurate flood control methods, such as soil moisture prediction based on deep learning (Fang et al. 2019), rainfall data crowdsourcing (Yang et al. 2019), and streamflow forecasting based on computer vision (Jiang et al. 2018), can provide new avenues for coping with such floods.

\section{Abbreviations}

TGR: Three Gorges Reservoir; YR: Yangtze River; YRB: Yangtze River Basin.

\section{Acknowledgements}

We are grateful to the support from Guangdong Provincial Key Laboratory of Soil and Groundwater Pollution Control, and State Environmental Protection Key Laboratory of Integrated Surface Water-Groundwater Pollution Control.

\section{Authors' contributions}

Conception of the work: SL, YZ, HS. Acquisition of the data: LF. Interpretation of the data: SL. Supervision: JC, VL. Writing-original draft: SL. Writing-review and editing: HS, YZ. All authors have read and approved the final manuscript.

\section{Funding}

This study was supported by the National Natural Science Foundation of China funded projects (51909117).

\section{Availability of data and materials}

The data and materials are available in the following books entitled "Rainstorm and flood of the Yangtze River in 1998" and "Rainstorm and flood of the Yangtze River in 2016".

\section{Declarations}

\section{Competing interests}

The authors declare that they have no competing interests.

\section{Author details}

${ }^{1}$ State Environmental Protection Key Laboratory of Integrated Surface Water-Groundwater Pollution Control, School of Environmental Science and Engineering, Southern University of Science and Technology, Shenzhen, Guangdong, China. ${ }^{2}$ Guangdong Provincial Key Laboratory of Soil and Groundwater Pollution Control, School of Environmental Science and Engineering, Southern University of Science and Technology, Shenzhen, Guangdong, China. ${ }^{3}$ Department of Civil Engineering, The University of Hong Kong, Hong Kong, China. ${ }^{4}$ Department of Engineering Systems and the Environment, University of Virginia, Charlottesville, VA 22904, USA.

Received: 5 Auqust 2021 Accepted: 12 October 2021

Published online: 21 October 2021

\footnotetext{
References

Fang K et al (2019) The value of SMAP for long-term soil moisture estimation with the help of deep learning. IEEE Trans Geosci Remote Sens 57(4):2221-2233
} 
Hydrology Bureau of Ministry of Water Resources (HBMWR), Hydrology Bureau of Yangtze River Water Resources Commission (HBYRWRC) (2002). Rainstorm and flood of the Yangtze River in 1998. China Water \& Power Press, Beijing, China.

Hou XJ et al (2020) Anthropogenic transformation of Yangtze Plain freshwater lakes: patterns, drivers and impacts. Remote Sens Environ 248:111998

Information Center of Ministry of Water Resources (ICMWR), Hydrology Bureau of Yangtze River Water Resources Commission (HBYRWRC) (2019). Rainstorm and flood of the Yangtze River in 2016. China Water \& Power Press, Beijing, China.

Jiang SJ et al (2018) A computer vision-based approach to fusing spatiotemporal data for hydrological modeling. J Hydrol 567:25-40

Liu SN et al (2020) Socioeconomic drought under growing population and changing climate: a new index considering the resilience of a regional water resources system. J Geophys Res Atmos 125(15):e2020JD033005

Nguyen TT et al (2019) Implementation of a specific urban water management-Sponge City. Sci Total Environ 652:147-162

Reynard NS et al (2017) The evolution of climate change guidance for fluvial flood risk management in England. Prog Phys Geogr 41(2):222-237
Shi HY et al (2020) A new method for estimation of spatially distributed rainfall through merging satellite observations, raingauge records, and terrain digital elevation model data. J Hydro Environ Res 28:1-14

Stevaux JC et al (2020) Changing fluvial styles and backwater flooding along the Upper Paraguay River plains in the Brazilian Pantanal wetland. Geomorphology 350:106906

van Noordwijk M et al (2017) Flood risk reduction and flow buffering as ecosystem services - part 1: theory on flow persistence, flashiness and base flow. Hydrol Earth Syst Sci 21(5):2321-2340

Yang P et al (2019) Reward-based participant management for crowdsourcing rainfall monitoring: an agent-based model simulation. Water Resour Res 55(10):8122-8141

Zong YQ, Chen XQ (2000) The 1998 Flood on the Yangtze, China. Nat Hazards 22:165-184

\section{Publisher's Note}

Springer Nature remains neutral with regard to jurisdictional claims in published maps and institutional affiliations.

\section{Submit your manuscript to a SpringerOpen ${ }^{\circ}$ journal and benefit from:}

- Convenient online submission

- Rigorous peer review

- Open access: articles freely available online

- High visibility within the field

- Retaining the copyright to your article

Submit your next manuscript at $\boldsymbol{\Delta}$ springeropen.com 